Chirurgia (2021) 116: 16-23

No. 1, January - February

Copyright@ Celsius

http://dx.doi.org/10.21614/chirurgia.116.1.16

\title{
When Should We Expect Curative Results of Neoadjuvant Treatment in Locally Advanced Rectal Cancer Patients?
}

\author{
Mihai-Teodor Georgescu ${ }^{1,2}$, Traian Patrascu ${ }^{1,3}$, Luiza Georgia Serbanescu' ${ }^{1}$, Rodica Maricela Anghel ${ }^{1,2}$, \\ Laurentia Nicoleta Gales ${ }^{1,2 *}$, Florin Teodor Georgescu ${ }^{1,4}$, Radu Iulian Mitrica ${ }^{1,2}$, Dragos Eugen Georgescu ${ }^{1,3}$ \\ "Carol Davila" University of Medicine and Pharmacy, Bucharest, Romania \\ ${ }^{2} 2^{\text {nd }}$ Department of Radiotherapy, "Prof. Dr. Al. Trestioreanu” Institutue of Oncology, Bucharest, Romania \\ ${ }^{3} 1^{\text {st }}$ Department of Surgery, "Dr. Ion Cantacuzino" Hospital, Bucharest, Romania \\ ${ }^{4}$ Department of Surgery, Bucharest Emergency Hospital, Romania
}

*Corresponding author: Laurentia Nicoleta Gales, MD

"Carol Davila" University of Medicine and Pharmacy, Bucharest, Romania

E-mail: laurentia.gales@yahoo.com

\section{Rezumat \\ Când ne-am putea aștepta la un răspuns complet la tratamentul neoadjuvant pentru pacienții cu cancer de rect local avansat?}

Această revizuire a literaturii recent publicate îşi propune să rezume datele publicate cu privire la răspunsul patologic complet în urma tratamentului neoadjuvant la pacienții cu cancer rectal avansat local biopsiat. Articolele publicate referitoare la pacientii cu cancer rectal pCR au fost identificate prin utilizarea căutării în baza de date PubMed. Au fost selectate unsprezece articole relevante, pe baza tumorii, a tratamentului şi a raportării caracteristicilor pacientului. În concluzie, pacienții cu cancer rectal cu cele mai mari şanse de răspuns clinic sau patologic complet la tratamentul neoadjuvant sunt bărbați, cu vârsta de aproximativ 60 de ani, diagnosticați cu cancer rectal local diferențiat bine sau moderat.

Cuvinte cheie: rect, neoadjuvnt, chimiordioterapie, răspuns complet

\section{Abstract}

This review on recently published literature aims to summarize published data on pathologic complete response following neoadjuvant treatment in biopsy proven locally advanced rectal cancer patients. Published articles referring to pCR rectal cancer patients 
were identified using PubMed search. Eleven relevant articles were selected, based on tumor, treatment, and patient characteristics reporting. As a conclusion, rectal cancer patients with the highest chances of complete clinical or pathological response to neoadjuvant treatment are males, who are around 60 years, diagnosed with well or moderate differentiated locally advanced rectal cancer.

Key words: rectum, neoadjuvant, chemoradiotherapy, complete response

\section{Introduction}

Colorectal cancer (CRC) is the most common diagnosed type of cancer of the digestive tract and the $3^{\text {rd }}$ most frequent type of cancer worldwide for both sexes (1). Its aggressivity is confirmed by the high mortality rates, in United States of America estimates suggesting that from 147.950 individuals diagnosed with this disease, 53.200 will die as a consequence of it (2). Although official data for CRC incidence and mortality is lacking for year 2020, starting 2012 methods of projecting the total numbers of new cases and deaths of CRC are available $(3,4)$. Considering current literature data, we can conclude that CRC is more frequent and has higher mortality rates in females compared to males (5).

After reviewing the latest published data, we consider the "colorectal cancer" category obsolete due to the fact that currently clinical, treatment and epidemiological data have been reported, and that colon cancer and rectal cancer should be discussed as separate diseases (6).

Locally and regionally advanced rectal cancer rates remain high worldwide, probably due to the low number of countries, considering the worldwide mortality rates, which implemented national screening programs for this disease. For stages II and III, rectal cancer survival rates are ranging between $80 \%$ and $50 \%$. However, variations still exist, probably due to individual and treatment related factors (6).

Regarding rectal cancer treatment, surgery remains the main therapeutic option according to current international guidelines $(7,8)$, even for the (oligo)metastatic stages. However, especially for low and middle rectal cancer, the rates of sphincter-preservation procedures remain low, with important decrease in patient's quality of life (QoL).

Preoperative chemoradiotherapy for locally advanced rectal cancer has been associated with increased local control and survival rates. Moreover, neoadjuvant chemoradiotherapy increased not only negative margin tumor resection rates, but also sphincter-sparring surgery rates (9).

We reviewed current literature databases and selected studies that focused on rectal cancer patients that underwent neoadjuvant chemoradiotherapy and had pathologic complete response (pCR), coded ypT0 N0. The purpose was to identify the main characteristics of rectal cancer patients, that have the highest chances of complete response following pre-operative treatment, focusing on radiotherapy.

\section{Materials and Methods}

We conducted a systematic search of current available electronic databases, in order to identify studies that focused on pCR rectal patient's characteristics. Published articles referring to $\mathrm{pCR}$ rectal cancer patients were identified by using PubMed search on MeSH headings "rectal cancer" AND "complete response". Titles and abstracts screened for data "preoperative OR neoadjuvant AND radiotherapy OR irradiation AND chemotherapy AND/OR chemoradiotherapy", were collated. Reference lists from the selected articles were evaluated in order to add other 
pertinent articles. Duplicate studies were excluded after this primary analysis. Conference abstracts, scientific letters, case reports, and studies not reporting patient population characteristics were excluded.

\section{Results}

Figure 1 presents the study selection process. Initially, 2805 studies were identified. Studies that were duplicated or that had irrelevant content were excluded. After checking the study exclusion criteria, 30 studies remained. In order to avoid more duplicates, another 8 studies and 3 meta analyses were excluded.

Although 7 studies were not reporting all study selected data, they were still used due to the large patient population, finally resulting 19 studies, from which 11 totally fulfilled study criteria. These studies and the selected study criteria are presented in Table 1.

\section{Discussions}

We reviewed institutional and multicenter analyses to identify the rectal cancer patients that had a pCR following neoadjuvant chemoradiotherapy, so that we could find certain patient, tumor, and treatment related features associated with higher chances of responding following neoadjuvant treatment with a complete response.

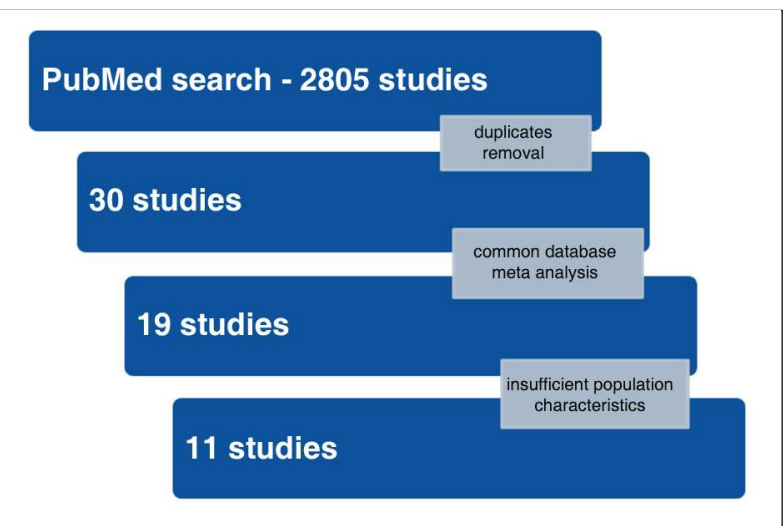

Figure 1. Study research and select process

\section{Patient Related Characteristics}

We previously mentioned that CRC is the $3^{\text {rd }}$ most common and the $4^{\text {th }}$ deadliest cancer in men, compared to women, for whom the $2^{\text {nd }}$ most frequent and the $3^{\text {rd }}$ deadliest (20). Considering that, some might expect that complete response rates would favor female patients. However, CRC studies on epidemiological data were not only focusing on rectal cancer patients. In 2012, Hansen IO et al. literature review (21) reported that female patients had presented more often with right colon cancer, which they also found to be more deadly than left sided colon cancer, which was more frequent in male patients. This would explain the latest epidemiological data.

Table 1. List of studies used in this review

\begin{tabular}{lcccccccc}
\hline & $\begin{array}{c}\text { Mean Age } \\
\text { (years) }\end{array}$ & $\begin{array}{c}\text { Majorit. } \\
\text { Gender }\end{array}$ & Stage & $\begin{array}{c}\text { Differentiation } \\
\text { grade }\end{array}$ & $\begin{array}{c}\text { Total RT } \\
\text { dose }\end{array}$ & $\begin{array}{c}\text { Concurrent } \\
\text { CHT }\end{array}$ & $\begin{array}{c}\text { Time until } \\
\text { surgery (weeks) }\end{array}$ & $\begin{array}{c}\text { PcR } \\
\text { (No pts.) }\end{array}$ \\
\hline Aguilar et. al. (9) & 57 & M & III & G1-2 & 50 Gy & Yes & 5.7 & 21 \\
\hline Hughes et al. (10) & 71 & M & II & NA & 45 Gy & Yes & 15 & 23 \\
\hline Capirici et al. (11) & 63 & M & II-III & NA & 50 Gy & Yes & 7.9 & 499 \\
\hline Yeo et al. (12) & 56 & M & III & G1-2 & 50 Gy & Yes & 7.5 & 304 \\
\hline Tulchinsky et al. (13) & 61 & M & II-III & NA & $45-50$ Gy & Yes & 7 & 26 \\
\hline Habr-Gama et al. (14) & 58 & M & I-III & NA & 54 Gy & Yes & 37 & cCr: 22 pCR: 5 \\
\hline Maas et al. (15) & 61 & M & I-III & NA & $45-50.4$ Gy & Yes & NA & 484 \\
\hline Decampos-Lobato et al. (16) & 54 & M & II-III & NA & 50.4 Gy & Yes & 8 & 58 \\
\hline Zorrcolo et al. (17) & 61 & M & II-III & NA & 50.4 Gy & Yes & 9.5 & 300 \\
\hline Dossa et al. (18) & 59.5 & M & I-III & G2 & $45-54$ Gy & Yes & 7 & 2455 \\
\hline Kuan et al. (19) & 61 & M & II-III & G2 & $40-50$ Gy & Yes & 7 & 259 \\
\hline
\end{tabular}


However, our research focused on rectal cancer only patients, and what we identified is that although there were some studies that did not focus on this characteristic, most of the selected studies have unanimously reported that $\mathrm{pCR}$ rates are higher in males than in female patients.

Age was another characteristic that we considered necessary to evaluate, due to the fact that age related literature reported data suggesting that in certain countries, like United Kingdom, incidence rates were higher in male rectal cancer patients than in females, for patient population above 45 years. This incidence gap between the two genders widened proportionally with age increase, the highest ratio being reported for the 70-74 years patient population. Furthermore, it has been shown that women exhibit delayed colorectal cancer development compared to men. In our literature review, all studies reported median age for the enrolled patients, resulting in a median age of 61 years for the pCR rectal cancer patients.

One of the drawbacks of our study was the lack of data regarding patient related comorbidities. Current literature data (22) suggests that toxicity following radiation to the pelvis is more common in diabetics and increases the risk of fecal incontinence.

\section{Tumor Related Characteristics}

For oncological patients, clinical stage remains the main tumoral prognostic factor regarding survival data. In the studies selected for this metanalysis, most of the rectal cancer patients who were reported as pCR-ers to neoadjuvant chemoradiotherapy, were diagnosed with locally advanced (stage II-III) disease. This was probably due to the fact that neoadjuvant treatment is recommended by most of the treatment guidelines in these stages for rectal cancer patients. However, although 2 of the reviewed studies $(9,12)$ focused solely on stage III rectal cancer, most studies enrolled in our literature review reported results stages II and III biopsy proven rectal cancer, 4 studies $(14,15,18,23)$ also reviewed data of stage I rectal cancer patients for whom pCR was achieved.

Cancer cells differentiation grade is already known to be an important predictive factor when we are referring to radiotherapy response. In previously published studies (24) for patients with rectal cancer undergoing radiotherapy, the differentiation degree is one of the main factors influencing tumor downstaging and residual tumor cell density. Our literature search results found that only 4 studies $(9,12,18,19)$ reported this characteristic of cancer cells for rectal cancer pCR patients. These studies confirmed that following neoadjuvant chemoradiotherapy, the highest $\mathrm{pCR}$ rates were achieved for well and moderately differentiated rectal tumors.

One of the drawbacks of this study was the lack of data regarding imunohistochemestry and pCR relationship. Current literature data focusing on pathological characteristics of rectal tumor cells report the importance of imunohistochemical tumor characteristics, such as p21, p53 and ki67 values, as important predictive factors for tumor shrinkage following neoadjuvant chemoradiotherapy (25-27).

\section{Treatment Related Characteristics}

All studies focusing on pCR in rectal cancer patients that underwent neoadjuvant chemoradiotherapy were used.

Regarding radiotherapy, it is widely recognized that its main purpose in this treatment phase is to downsize or downstage large tumors. Although, not all patients respond favorably to radiotherapy, some studies $(14,15,18,23)$ reported its use as neoadjuvant treatment event in smaller tumors. A recent analysis of the NCD in 2017 (28) reported a pCR rate of $13 \%$ in an overall cohort of 27532 patients. In none of the reviewed literature reported data short course radiotherapy or altered fractionation radiotherapy schedules were used. A vast majority of the studies we reviewed reported the use of neoadjuvant radiotherapy up to a total dose of 45 to $50 \mathrm{~Gy}$. However, in 4 studies $(14,23,29,30)$, radiation doses above 50 Gy were used, with only one 
study (23) reporting total doses of 60 Gy in the neoadjuvant treatment setting. A recent study (31) reviewed radiotherapy parameters that were most associated with pCR in rectal cancer patients and reported that total dose was the main radiation factor influencing $\mathrm{pCR}$ rates. Another study (32) suggested that increasing tumor radiation dose, without neoadjuvant treatment prolongation, should be a feasible way of achieving better tumor response. Therefore, preoperative long course radiotherapy associated with simultaneously integrated boost (SIB) up to doses above 50 Gy on the tumor, achieved a very high tumor response rate without increasing acute or late toxicity (33). Common limitations of the recent studies focusing on radiotherapy were the use and the timing of chemotherapy drugs, because that would induce higher variability in tumor response to neoadjuvant chemoradiotherapy (34).

Regarding chemotherapy, in most studies reporting pCR for rectal cancer patients following neoadjuvant chemoradiotherapy, infusional 5FU was used as monotherapy, 5 days/week, weeks 1 and 5 of radiotherapy. All studies from our metanalysis reported data regarding the type of chemotherapy used, and what we observed was that multi-drug chemotherapy regimens were usually used concurrently with lower doses of radiotherapy, due to the risk of cumulative toxicity, especially hematological. Few studies used high doses of radiotherapy and concurrent polichemotherapy, but unfortunately few data regarding patient characteristics was provided. As expected, most studies found that neoadjuvant polichemotherapy and radiotherapy were associated with a slight increase in pCR rates and significant increase in grade 3/4 toxicities, compared to concurrent monochemotherapy and radiotherapy (27-30). A study's results also suggest an extremely aggressive neo-adjuvant treatment comprising of polichemotherapy with $5 \mathrm{FU}$ and high dose radiotherapy do not increase the rates of $\mathrm{pCR}$ patients $(31,32)$.

Based on other studies $(35,36)$ reported data, Urick et al (37) tested the enhancement of 5FU-induced in-vivo and in-vitro radio- sensitization, and found that its enhancement and cytotoxicity are increased, resulting in an increase in radiation sensitization, further resulting in an increase in mitotic catastrophe and apoptosis, a reduction in Stat-3 phosphorylation, and a reduction in Survivin expression. Considering that infusional 5FU shows encouraging results, Capecitabine is recommended to be administered $825 \mathrm{mg} / \mathrm{m}^{2}$, twice daily for 7 days a week, ideally 1-2 hours before radiotherapy $(38,39)$. This proves to be most effective, due to its constant citotoxic effect that prevents tumoral regrowth, without an increase in toxicity (40). Due to the good tolerability of neoadjuvant chemoradiotherapy with Capecitabine, recent studies started to emerge reevaluating the addition of other chemotherapy drugs in the Capecitabine and radiotherapy neoadjuvant schedule, with promising results regarding $\mathrm{pCR}$ rates in rectal cancer patients (41). However, after literature research, case reports $(42,43)$, and modest cohort size studies were found to reporting complete response following neoadjuvant concurrent radiotherapy and polichemotherapy.

Usually, rectal curative surgery is undergone at 6-8 weeks following neoadjuvant chemoradiotherapy. However, retrospective studies revealed that an interval prolongation beyond 8 weeks is associated with higher rates of $\mathrm{pCR}$. Studies evaluating $\mathrm{pCR}$ rates in rectal cancer patients who underwent radical surgery following neoadjuvant chemoradiotherapy, showed that delaying surgery above 8 weeks results in an almost doubling of pCR rates, compared to those that were operated in less than 7 weeks, from approximately $15 \%$ to $27 \%$ respectively. (44-47). Some of these authors $(44,45)$ have also suggested that delaying surgery was also associated with better local control, disease-free survival, and cause-specific survival.

Most surgeons are reluctant to this delayed surgery approach due to the risk of late radiation side effects such as fibrosis, although, studies on this are also emerging, and the reported data is encouraging, suggesting no increased rates of blood loss, blood transfusions, 
operative time, post-operative complications, length of hospital stay, or overall morbidity/ toxicity $(45,47)$.

Although in most studies that we reviewed $(48,49)$ surgery was delayed with at least 7 weeks, in Habr-Gamma et al. study (14), the mean interval between neoadjuvant treatment completion and surgical resection was $37.7 \pm 18.4$ weeks due to a watch and wait approach, radical surgery being delayed as much as possible and replaced for suspected residual disease with a conservative approach such as full-thickness local excision.

Jian-Wei Zhang et al (50) proposed in their research a nomogram for predicting pathological complete response and tumor downstaging in patients with locally advanced rectal cancer, on the basis of a randomized clinical trial. The authors concluded that tumor length, tumor circumferential extent, distances from the anal verge, clinical $\mathrm{T}$ category neoadjuvant treatment regimen were significantly associated with good tumor downstaging.

More research is still needed in this area. Although it is widely accepted that prior pelvic tumor irradiation and local anatomy $(51,52)$ might lead to an increased risk of developing rectal cancer tumors, there islimited data regarding the response of these radiation induced tumors to neoadjuvant chemoradiotherapy.

\section{Conclusions}

This review's objective was to identify a pattern of features for rectal cancer patients undergoing neoadjuvant chemoradiotherapy who have the highest $\mathrm{pCR}$ rates. As previously mentioned, more data like imunohistochemestry and molecular biology testing would have certainly helped us. As a conclusion, rectal cancer patients with the highest chances of complete clinical or pathological response to neoadjuvant treatment are males, aged around 60 years, diagnosed with well or moderate differentiated locally advanced rectal cancer. For these patients, the most appropriate neoadjuvant treatment in order to achieve complete response before radical surgery, should be concurrent chemoradiotherapy. Radiotherapy should be administered up to a total dose of $50 \mathrm{~Gy}$, using a conventional fractionation regimen, preferably with a highly conformal technique like IMRT/VMAT. Concurrent chemotherapy should consist of 5FU administered intravenously, as a bolus, days 1 and 21 of treatment, or oral Capecitabine $825 \mathrm{mg} / \mathrm{m}^{2}$, twice daily, one administration with 1-2 hours before radiotherapy session, 7 days/week. If Capecitabine is preferred as concurrent chemotherapy and highly conformal radiotherapy is used, other chemotherapy drugs (ex. Leucovorin, Oxaliplatin) can be used concurrently.

Postneoadjuvant treatment evaluation should be done at least 8 weeks following the end of treatment. We recommend that if clinical complete response is achieved, a tumoral bed blind biopsy should be done. Also, patients obtaining pCR should be actively monitored. Adjuvant chemotherapy following neoadjuvant treatment, in the absence of surgery should be considered, not necessarily to reduce relapse rate, but to prevent disease spreading.

\section{Conflicts of Interest}

All authors declare no conflicts of interest exist.

\section{References}

1. Ferlay J, Colombet M, Soerjomataram I, Mathers C, Parkin DM, Piñeros M, et al. Global and Regional Estimates of the Incidence and Mortality for 38 Cancers: GLOBOCAN 2018. Lyon: International Agency for Research on Cancer/World Health Organization; 2018

2. Islami F, Goding Sauer A, Miller KD, Siegel RL, Fedewa SA, Jacobs EJ, et al. Proportion and number of cancer cases and deaths attributable to potentially modifiable risk factors in the United States. CA Cancer J Clin. 2018:68(1):31-54. Epub 2017 Nov 21.

3. Chen HS, Portier K, Ghosh K, Naishadham D, Kim HJ, Zhu L, et al. Predicting US- and state-level cancer counts for the current calendar year: part I: evaluation of temporal projection methods for mortality. Cancer. 2012;118(4):1091-9.

4. Zhu L, Pickle LW, Ghosh K, Naishadham D, Portier K, Chen HS, et al. Predicting US- and state-level cancer counts for the current calendar year: part II: evaluation of spatiotemporal projection methods for incidence. Cancer. 2012;118(4):1100-9.

5. Rawla P, Sunkara T, Barsouk A. Epidemiology of colorectal cancer: incidence, mortality, survival, and risk factors. Prz Gastroenterol. 2019;14(2):89-103 
6. Yin D, Morris CR, Bates JH, German RR. Effect of misclassified underlying cause of death on survival estimates of colon and rectal cancer. J Natl Cancer Inst. 2011;103(14):1130-3.

7. https://www.nccn.org/professionals/physician_gls/pdf/rectal.pdf, accessed 03.08.2020

8. Glynne-Jones R, Wyrwicz L, Tiret E, Brown G, Rödel C, Cervantes A, et al. Rectal cancer: ESMO Clinical Practice Guidelines for diagnosis, treatment and follow-up. Ann Oncol. 2017;28(suppl_4): iv22-iv40.

9. García-Aguilar J, Hernandez de Anda E, Sirivongs P, Lee SH, Madoff RD, Rothenberger DA. A pathologic complete response to preoperative chemoradiation is associated with lower local recurrence and improved survival in rectal cancer patients treated by mesorectal excision. Dis Colon Rectum. 2003; 46(3):298-304.

10. Hughes R, Glynne-Jones R, Grainger J, Richman P, Makris A Harrison $\mathrm{M}$, et al. Can pathological complete response in the primary tumour following pre-operative pelvic chemoradiotherapy for T3-T4 rectal cancer predict for sterilisation of pelvic lymph nodes, a low risk of local recurrence and the appropriateness of local excision? Int J Colorectal Dis. 2006;21(1):11-17.

11. Capirci C, Valentini V, Cionini L, De Paoli A, Rodel C, Glynne-Jones $\mathrm{R}$, et al. Prognostic value of pathologic complete response after neoadjuvant therapy in locally advanced rectal cancer: long-term analysis of 566 ypCR patients. Int J Radiat Oncol Biol Phys. 2008; 72(1):99-107.

(12. Yeo SG, Kim DY, Kim TH, Chang HJ, Oh JH, Park W, et al. Pathologic complete response of primary tumor following preoperative chemoradiotherapy for locally advanced rectal cancer: long-term outcomes and prognostic significance of pathologic nodal status (KROG 09-01). Ann Surg. 2010;252(6):998-1004.

13. Tulchinsky H, Shmueli E, Figer A, Klausner JM, Rabau M. An interval $>7$ weeks between neoadjuvant therapy and surgery improves pathologic complete response and disease-free survival in patients with locally advanced rectal cancer. Ann Surg Oncol. 2008;15(10):2661-2667.

14. Habr-Gama A, Perez RO, Sabbaga J, Nadalin W, Săo Juliăo GP, Gama-Rodrigues J. Increasing the rates of complete response to neoadjuvant chemoradiotherapy for distal rectal cancer: results of a prospective study using additional chemotherapy during the resting period. Dis Colon Rectum. 2009;52(12):1927-1934.

15. Maas M, Nelemans PJ, Valentini V, Das P, Rödel C, Kuo LJ, et al. Long-term outcome in patients with a pathological complete response after chemoradiation for rectal cancer: a pooled analysis of individual patient data. Lancet Oncol. 2010;11(9):835-844.

16. de Campos-Lobato LF, Stocchi L, da Luz Moreira A, Geisler D, Dietz DW, Lavery IC, et al. Pathologic complete response after neoadjuvant treatment for rectal cancer decreases distant recurrence and could eradicate local recurrence. Ann Surg Oncol. 2011;18(6): 1590-1598.

17. Zorcolo L, Rosman AS, Restivo A, Pisano M, Nigri GR, Fancellu A, et al. Complete pathologic response after combined modality treatment for rectal cancer and long-term survival: a meta-analysis. Ann Surg Oncol. 2012;19(9):2822-2832.

18. Dossa F, Acuna SA, Rickles AS, Berho M, Wexner SD, Quereshy FA et al. Association Between Adjuvant Chemotherapy and Overall Survival in Patients With Rectal Cancer and Pathological Complete Response After Neoadjuvant Chemotherapy and Resection. JAMA Oncol. 2018;4(7):930-937

19. Kuan FC, Lai CH, Ku HY, Wu CF, Hsieh MC, Liu TW, et al. The survival impact of delayed surgery and adjuvant chemotherapy on stage II/III rectal cancer with pathological complete response after neoadjuvant chemoradiation. Int J Cancer. 2017;140(7):16621669

20. White A, Ironmonger L, Steele RJC, Ormiston-Smith N, Crawford C, Seims A. A review of sex-related differences in colorectal cancer incidence, screening uptake, routes to diagnosis, cancer stage and survival in the UK. BMC Cancer. 2018;18(1):906.
21. Hansen IO, Jess P. Possible better long-term survival in left versus right-sided colon cancer - a systematic review. Dan Med J. 2012; 59(6):A4444.

22. van der Valk M, Hilling D, Bastiaannet E, Meershoek-Klein KE, Beets G. Figueiredo N, et al. Long-term outcomes of clinical complete responders after neoadjuvant treatment for rectal cancer in the International Watch \& Wait Database (IWWD): an international multicentre registry study. Lancet. 2018;391(10139):2537-2545.

23. Mohiuddin M, Regine WF, John WJ, Hagihara PF, McGrath PC, Kenady DE, et al. Preoperative chemoradiation in fixed distal rectal cancer: dose time factors for pathological complete response. Int J Radiat Oncol Biol Phys. 2000;46(4):883-8.

24. Berger C, de Muret A, Garaud P, Chapet S, Bourlier P, ReynaudBougnoux A, et al. Preoperative radiotherapy (RT. for rectal cancer: predictive factors of tumor downstaging and residual tumor cell density (RTCD): prognostic implications. Int J Radiat Oncol Biol Phys. 1997;37(3):619-27.

25. Shinto E, Omata J, Sikina A, Sekizawa A, Kajiwara Y, Hayashi K, et al. Predictive immunohistochemical features for tumour response to chemoradiotherapy in rectal cancer. BJS Open. 2020;4(2):301-9.

26. Georgescu TF, Turculet CS, Enache V, Georgescu DE, Georgescu MT, Beuran M. The importance of immunohistochemistry analysis of p53 and Bcl-2 in patients with preoperative oncological therapy for rectal cancer. Romanian Journal of Medical practice 2019; 15(2):199-203

27. Serbanescu LG, Voica I, Georgescu MT, Gales LN, Anghel RM. P-213 Role of reactive oxygen species, IL-6 and KRAS mutation in rectal adenocarcinoma. Annals of Oncology 2020, 31:S159-S160.

28. Lorimer PD, Motz BM, Kirks RC, Boselli DM, Walsh KK, Prabhu RS, et al. Pathologic Complete Response Rates After Neoadjuvant Treatment in Rectal Cancer: An Analysis of the National Cancer Database, Surg Oncol. 2017;24(8):2095-2103.

29. Stipa F, Chessin DB, Shia J, Paty PB, Weiser M, Temple LK, et al. A pathologic complete response of rectal cancer to preoperative combined-modality therapy results in improved oncological outcome compared with those who achieve no downstaging on the basis of preoperative endorectal ultrasonography. Ann Surg Oncol. 2006;13(8):1047-1053.

30. Hartley A, Ho KF, McConkey C, Geh Jl. Pathological complete response following pre-operative chemoradiotherapy in rectal cancer: analysis of phase II/III trials. Br J Radiol. 2005;78(934):934-8.

31. Hall MD, Schultheiss TE, Smith DD, Fakih MG, Wong JY, Chen YJ. Effect of increasing radiation dose on pathologic complete response in rectal cancer patients treated with neoadjuvant chemoradiation therapy. Acta Oncol. 2016; 55(12):1392-1399.

32. Ballonoff A, Kavanagh B, McCarter M, Kane M, Pearlman N, Nash $\mathrm{R}$, et al. Preoperative capecitabine and accelerated intensitymodulated radiotherapy in locally advanced rectal cancer: a phase II trial, Am J Clin Oncol. 2008;31(3):264-270.

33. Picardi V, Macchia G, Guido A, Giaccherini L, Deodato F, Farioli A, et al. Preoperative Chemoradiation With VMAT-SIB in Rectal Cancer: A Phase II Study. Clin Colorectal Cancer. 2017;16(1):16-22.

34. Sauer R, Becker H, Hohenberger W, Rödel C, Wittekind C, Fietkau $\mathrm{R}$, et al. Preoperative versus postoperative chemoradiotherapy for rectal cancer. N Engl J Med. 2004;351(17):1731-40.

35. Bosset JF, Calais G, Mineur L, Maingon P, Radosevic-Jelic L, Daban A, et al. Enhanced tumorocidal effect of chemotherapy with preoperative radiotherapy for rectal cancer: preliminary results EORTC 22921. J Clin Oncol. 2005;23(24): 5620-7.

36. Gerard JP, Conroy T, Bonnetain F, Bouche 0, Chapet 0, ClosonDejardin MT et al. Preoperative radiotherapy with or without concurrent fluorouracil and leucovorin in T3-4 rectal cancers: results of FFCD 9203. J Clin Oncol. 2006;24(28):4620-5.

37. Urick ME, Chung EJ, Shield WP 3rd, Gerber N, White A, Sowers A, et al. Enhancement of 5-fluorouracil-induced in vitro and in vivo radiosensitization with MEK inhibition. Clin Cancer Res. 2011; 17(15):5038-5047. 
38. Bujko K, Nowacki MP, Nasierowska-Guttmejer A, Michalski W, Bebenek M, Pudełko M, et al. Sphincter preservation following preoperative radiotherapy for rectal cancer: report of a randomized trial comparing short-term radiotherapy vs. conventionally fractionated radiochemotherapy. Radiother Oncol. 2004;72(1):15-24.

39. Schumller J, Cassidy J, Dumont E, Roos B, Durston S, Banken L, et al. Preferential activation of capecitabine in tumor following oral administration to colorectal cancer patients. Cancer Chemother Pharmacol. 2000;45(4):291-7.

40. Sawada N, Ishikawa T, Sekiguchi F, Tanaka Y, Ishitsuka H. X-ray irradiation induces thymidine phosphorylase and enhances the efficacy of capecitabine (Xeloda) in human cancer xenografts. Clin Cancer Res. 1999;5(10):2948-53.

41. Reigner B, Blesch K, Weidekamm E. Clinical pharmacokinetics of capecitabine. Clin Pharmacokinet. 2001;40(2):85-104.

42. Georgescu DE, Georgescu MT, Bobirca FT, Georgescu TF, Doran H, Patrascu T. Synchronous Locally Advanced Rectal Cancer with Clinical Complete Remission and Important Downstaging after Neoadjuvant Radiochemotherapy - Personalised Therapeutic Approach. Chirurgia (Bucur). 2017;112(6):726-733.

43. Keiji M, Kohei O, Yuka O, Takahiro Y, Tsukamoto M, Yoshihisa F et al. Case Report of a Clinically Complete Response in a Rectal Cancer Patient after Chemoradiotherapy with a 2-year Watch and Wait Approach. Nihon Gekakei Rengo Gakkaishi. J Jap Colleg Surg. 2017;42(5):835-840.

44. Glynne-Jones R, Dunst J, Sebag-Montefiore D. The integration of oral capecitabine into chemoradiation regimens for locally advanced rectal cancer: how successful have we been? Ann Oncol. 2006;17(3):361-371.

45. Hu, YH, Wei JW, Chang H, Xiao WW, Lin JZ, Cai MY, et al. The high PCR rate of sandwich neoadjuvant treatment in locally advanced rectal cancer may translate into a better long-term survival benefit: 5-year outcome of a Phase II clinical trial. Cancer Manag Res. 2018;10:4363-4369.

46. Wolthuis AM, Penninckx F, Haustermans K, De Hertogh G, Fieuws $S$, Van Cutsem E, et al. Impact of interval between neoadjuvant chemoradiotherapy and tme for locally advanced rectal cancer on pathologic response and oncologic outcome. Ann Surg Oncol. 2012;19(9):2833-41.

47. de Campos-Lobato LF, Geisler DP, da Luz Moreira A, Stocchi L, Dietz D, Kalady MF. Neoadjuvant therapy for rectal cancer: The impact of longer interval between chemoradiation and surgery. J Gastrointest Surg. 2011;15(3):444-50. Epub 2010 Dec 8.

48. Kalady MF, de Campos-Lobato LF, Stocchi L, Geisler DP, Dietz D, Lavery IC, et al. Predictive factors of pathologic complete response after neoadjuvant chemoradiation for rectal cancer. Ann Surg. 2009;250(4):582-9.

49. Garcia-Aguilar J, Smith DD, Avila K, Bergsland EK, Chu P, Krieg RM, et al. Optimal timing of surgery after chemoradiation for advanced rectal cancer: Preliminary results of a multicenter, nonrandomized phase ii prospective trial. Ann Surg. 2011;254(1):97-102.

50. Zhang JW, Cai Y, Xie XY, Hu HB, Ling JY, Wu ZH, et al. Nomogram for predicting pathological complete response and tumor downstaging in patients with locally advanced rectal cancer on the basis of a randomized clinical trial. Gastroenterol Rep (0xf). 2020;8(3):234-241.

51. Georgescu MT, Anghel R. Variation in uterus position prior to brachytherapy of the cervix: A case report. J Med Life. 2017; 10(1):90-3.

52. Georgescu MT, Moldoveanu VG, lleanu BV, Anghel R. Dosimetric influence of uterus position in cervix cancer high-dose-rate brachytherapy. Rom J Phys. 2016;61(9-10):1557-66. 